\title{
COMMENT
}

DOI: 10.1057/s41599-018-0168-7

\section{UK-Russia relations: poisoned chalice or silver linings?}

Maxine David (1) ${ }^{1}$

\begin{abstract}
With the poisoning of the former Russian spy, Sergei Skripal, the British Government quickly accused Russia of committing an unlawful use of force on British territory and retaliated. The UK's diplomatic resources were deployed effectively, as more than 20 allies swiftly stood up in solidarity. Assuming the Kremlin is culpable, Vladimir Putin may have unwittingly given Theresa May an opportunity to be in the vanguard of those facing up to Russia's challenge and to retrieve something of Britain's diminishing reputation. But May will do well to remember that with alliances come expectations. This article examines the measures taken for signs of No 10's sincere commitment to establishing an effective Russia policy but argues too that there is much evidence that little will change. Only with dedicated intent will substance be added to the rhetoric of 'Global Britain'.
\end{abstract}

\footnotetext{
${ }^{1}$ Leiden University, Leiden, Netherlands. Correspondence and requests for materials should be addressed to M.D. (email: m.e.l.david@hum.leidenuniv.nl)
} 


\section{Background}

he United Kingdom's relationship with Russia has long been a difficult one. The March 2018 use of the military grade nerve agent novichok on British territory, and the UK's accusation that the attack was Russian state sponsored was a particularly potent signifier of that relationship but hardly the only one. That attempt to kill the former Russian spy Sergei Skripal was not the first of its kind. Britain had been here before with the killing of Alexander Litvinenko in London in 2006, in which a radioactive poison, polonium, was used. The early investigation and eventual enquiry into Litvinenko's death concluded the trail led firmly back to Moscow. Investigations had hardly begun in the Skripal instance before the British Government pointed the finger firmly at Moscow again. The accusation may have come too far ahead of the investigation and evidence but even so, few with a history of watching Russia doubted that the trail led back to Moscow, 'probably' ${ }^{1}$ the Kremlin itself. Both cases matter, not least because both times members of the wider British public were also put at risk, leading in the case of the Skripal poisonings in Salisbury, to the immediate hospitalisation of a policeman, as well as Sergei Skripal's daughter, Yulia. A few months later, on June 30, two members of the public, Dawn Sturgess and Charlie Rowley, happened upon a discarded specimen of the novichok and were exposed to it. Sturgess would pay the ultimate price for the reckless act of the perpetrators.

As if these incidences are not enough, it should be remembered too that these may well not be the only cases of the Kremlin exacting revenge on those it deems guilty of betrayal. Following the attempt on Skripal's life, the Chair of the Home Affairs Select Committee, Yvette Cooper, also called for the deaths of other Russians in the UK to be reviewed, a request taken seriously by the then Home Secretary, Amber Rudd. No state, particularly one that has, in the context of Brexit, been expounding on the need to 'take back control' can or should take lightly such assaults on its sovereignty. In both cases, No 10 responded but it is the argument here that this persistent need to respond and react is itself an indication of a policy vacuum and the lack of proactive strategic thinking. Assuming No 10 is right and the Skripal poisonings can be laid at the door of the Kremlin, what do two such blatant, heedless attacks say about the regard in which Russia holds the UK? Litvinenko's death should surely have been enough to direct the British government to work on a Russia policy, or at least a strategy directed at deterrence, neither of which were forthcoming. The monstrous nature of the Skripal poisonings have offered both cause and opportunity for No 10 not only to hold the Kremlin's feet to the fire, but also to question its own complacency and to ensure that an effective policy emerges to combat the threat posed by Russia. Failure to do so is akin to granting a licence for future such attacks on the territory of the UK and other states that offer harbour to those seeking to escape dangerous regimes.

\section{The British assessment and response}

It is true that the Skripal poisonings look so far as if they have performed the function of a wake-up call and there are some things for which the Government can be congratulated. The expulsion of Russian diplomats was predictable; that May would secure the support of allies who also expelled Russian diplomats, 150 plus from NATO and 27 countries, was not. A May 2018 UK Parliamentary Report into Russian money in the UK outlined the various measures now underway to prevent the City of London acting as a locus for the laundering of money stolen from the Russian people (UK Parliament, 2018a), including the Magnitsky ${ }^{2}$ Amendment to the Sanctions and Anti-Money Laundering Bill and more customs and freight checks, as well as on private flights. Measures instituted previously are also being wielded, the Tier 1 visa process a case in point, with Roman Abramovich a high profile casualty in June of this year of the need now to demonstrate wealth has been accumulated honestly.

Nonetheless, while show ponies have their uses, what is really needed are carthorses to carry the burden in a system that has been designed to work effectively and be sustainable. The requirement for a systematic overhaul of the manner in which business in the City of London is conducted is not in doubt. The same May 2018 Parliamentary Report included evidence from witnesses who spoke of a long-term environment in which the desire to secure assets for London rather than losing them to other markets won out over ethical practices: essentially, therefore, it reported on how the City had facilitated corrupt activity, by extension undermining the importance of the rule of law. This was summed up to the Committee by the journalist, Luke Harding as: 'you steal in a place of legal nihilism and you offshore in a place of legal solidity'. Thus, while the scrutiny and measures being applied now are welcome we should not take for granted they will be sustained. The Skripal poisonings did not tell us anything fundamentally new about the Putin regime, witness Litvinenko, the annexation of Crimea, the downing of a passenger jet over Ukraine; whatever action taken after Salisbury may be appropriate now, it was appropriate many more years ago. The Skripal poisonings were simultaneously incidents that could not be ignored and useful in terms of providing a distraction from other problems Theresa May was and is facing at home, but it should not be presumed that they will serve in the longer term as a catalyst for a real overhaul of British foreign, and other, policy.

The failures to date to respond robustly to Russia are not due to Russia's actions having escaped the attention of Parliament and government; even a cursory survey of the materials of the Foreign Affairs Select Committee demonstrates that. Nor is it the case that the seriousness of the challenge presented by Russia has been insufficiently grasped, especially given the dangerously reckless methods selected for the killing of Alexander Litvinenko and the attempt to kill Sergei Skripal. It is the case, however, that knowledge and understanding of Russia has not translated into policy or strategy. Take, for instance, the Government's response to the Foreign Affairs Committee's Report published in March 2017 (UK Parliament, 2017b). Much reference is made to the UK working closely with international partners but little in the way of concrete initiatives are detailed; instead, the response is littered with references to how the Government 'works closely', 'condemns', 'expects'. One place that does give hope is in section 28 and the Committee's recommendation that investment be made in the FCO to ensure long-term analytical capabilities. Here, the Government response is long on detail, referring to greater resourcing in respect of staff, language skills, expertise. There is recognition that Russia cannot be the purview of just one arm of government, that what is required is 'that the whole of Government builds its Russia expertise' and that 'a deep understanding' of Eastern Europe and Central Asia must be built. In the next breath, however, in response to the Committee's very fair suggestion that a junior FCO ministerial role covering Russian and the Commonwealth of Independent States (CIS) should be created, the Government response is dismissive and there is little elsewhere to suggest we are seeing serious engagement from No 10 with what are actually structural problems. This does appear to have wrought one potentially fruitful effect, however, with others making efforts to adjust structures, such as to assist in information-sharing. In April 2018, the heads of Parliament's key committees, including Defence, Foreign Affairs, Home Affairs and the Treasury joined forces to create a body in which they could come together and coordinate their various works as they 
apply to inquiries into Russia, arguing, entirely rightly, that their 'work will be much more effective if it is coordinated' (Mairs, 2018).

\section{What needs to change?}

Such moves are welcome but are they enough? In an article published in 2000 but which could have been written today in terms of continued applicability, Sir John Coles GCMG, former Permanent Under Secretary at the Foreign and Commonwealth Office (FCO), wrote about why foreign policy matters and his fears that British foreign policy was characterised less by substance than style. To take the first of these points, Russia has demonstrated, startlingly, the importance of maintaining a robust foreign policy. In a globalised world where people and money move so easily, and where other states firmly believe the foreign matters as much as the domestic, foreign policy matters. ${ }^{3}$ Neglect of it brings consequences for your own people, as well as others. The second of his points also applies today, where at both the macro and micro levels, a continued reliance on empty phrases rather than anything of import is evident. At the overarching, foreign policy level, there is the Government's 'Global Britain' narrative, its response to requests to detail the UK's place in the world after it leaves the EU (see, for instance, May, 2017). It denotes little that constitutes material change, however, such that in a March 2018 Report, the Foreign Affairs Select Committee argued that the FCO's 'description of Global Britain is [...] little more than a continuation of the FCO's current activities, with modest adjustments in some areas'. One expert witness, Sir Simon Fraser, like Coles a former Permanent Under Secretary at the FCO, said,

I am not sure exactly at the moment what Global Britain consists of. The Prime Minister has had two opportunities recently [...] to explain it further, but she has not taken them. It would be desirable if a bit more clarity and content were put behind the headline (UK Parliament, 2018b).

At the micro, Russia-specific level, there is also little of policy essence unless one considers the Government's response to the Foreign Affairs Committee adequate: 'The Prime Minister and the Foreign Secretary have made clear that our policy towards Russia is 'to engage but beware' (UK Parliament, 2017a). The sense that the UK is capable of responding in only limited, unimaginative ways is reinforced further by the fact that, in his first visit to the United States, the new (as of July 9th 2018) Foreign Secretary, Jeremy Hunt, called for the UK's 'allies to go further by calling on the European Union to ensure its sanctions against Russia are comprehensive, and that we truly stand shoulder to shoulder with the US' (Hunt, 2018). More sanctions and a reliance on an increasingly uncertain relationship are patently not enough to ensure Russia and others take the United Kingdom seriously.

Coles argued a prescription of six items was necessary to ensure substance in Britain's foreign policy, including that policymaking be prioritised, plans made, strategic thinking employed and purpose defined (Coles, 2000, p. 6), also making the point that Britain was not as influential in Russia and Eastern Europe (Coles, 2000, p. 7) as it could be. The Skripal poisonings are a symbol of the failure to address each of these, what must follow is a committed and sustained attempt to change that. As part of that, we must know first from the Government what its objectives are in regard to Russia. Second, we need to know what it thinks Russia's objectives are since this tells us something about how the Government conceives of Russia and understands its place in the world and its ambitions. Third, we need to know how No 10 thinks it can achieve its objectives and fourth, we must see resources committed and detailed strategies formulated that are designed to realise them.

\section{The barriers to change}

The obstacles are formidable in the current context of Brexit. In July 2017, the Head of the Civil Service talked of how 2,000 new Brexit-related roles had been created, of the injection of $£ 400$ million plus and of how more money and more appointments would be made in the coming year (Heywood, 2017). What he did not outline was what the cost was to other government needs and functions of directing these resources towards Brexit, to say nothing of what political and policy attention had been diverted from threats represented by external parties rather than on mitigating the effects of self-harm. It is the case that attention and resources have been turned outwards but these have been directed to trade and filling the ambassadorial functions overseas that will be lost upon the UK's exit from the EU. In other words, we have seen a diversion of resources away from the foreign policymaking that experts, like Coles, have long suggested we urgently need.

A second obstacle, also self-imposed, lies in the effects of leaving behind our closest, most wide-ranging (in terms of scope of activity) organisational membership. The Government response to the Foreign Affairs Committee spoke not only of how it worked with allies to combat the Russian threat but of the necessity of doing so, something Hunt has also reinforced, as above. It is therefore doubly unfortunate that the United Kingdom will shortly be leaving the European Union. Aside from the way the UK plays into Russia's hands, by undermining the European Union in a more wholesale fashion than the Kremlin could ever have hoped to achieve itself, No 10 should be concerned that the EU's unity on sanctions will be broken given new and worrying political developments in states such as Austria and Italy; Cyprus will also be one to watch if the City of London sends out a sustained message that dirty money is unwelcome there. The UK's departure will therefore remove one pillar of relative resolve from the EU, a voice that has experienced the weight of Russia's malign activity. From the UK's perspective, it is losing an important forum in which it could help shape wider European policy and strategy directed at combatting the threat posed by Russia and from which its own policymaking and strategising could benefit.

A further barrier lies in the fact that the threat posed by Russia is multi-faceted and directed at all levels of society, as seen most clearly by disinformation and propaganda activities. That the UK's government realises this is well documented, including in its responses set out in the various documents already cited here. One consequence of living in a society that protects the right to free speech is that the public is vulnerable to attempts to lie, to obfuscate, confuse and manipulate (Morgan, 2018; Polyakova and Fried, 2018). Under Putin, Russia has seen a return to form that is familiar to those who were watchers of the Soviet Union too (Legvold, 2014; Polyakova and Fried, 2018). In the longer term, it is important that distinctions are made between Russia and its political elites and Russians. The politicians and businesspeople of the future will come from among the general public. What thought then is being given to how the public of the future will be equipped with the aids to critical thought that they will need increasingly to navigate their way through the mass of information available to them? Thus, government needs to think about education, at all levels, as part of their strategy for combatting the threat Russia (and others) poses in the informational field. Continuing to prioritise STEM subjects over the Social Sciences and Humanities will have detrimental effects and mean resources will continue to need to be directed to building up the skills of those few civil servants linked to the Russia desk, versus a holistic 
way of government thinking that recognises the vulnerability of all society and therefore of the need to engender resilience of thought at the societal level.

\section{Leadership in a time of crisis}

The question of how much leadership matters is a vexatious one for foreign policy analysts. ${ }^{4} \mathrm{~A}$ number of factors render it more or less important, including the political system, the nature of the challenges any actor faces, the available resources and so on. Unarguably, however, there are times when good leadership matters significantly. Hermann and Hagan speak of moments of crisis when decision-making is most likely to be placed in the hands of a very small number of people $(1998$, p. 128) and of how, '[b]ased on their perceptions and interpretations, [leaders] build expectations, plan strategies, and urge actions on their governments that conform with their judgements about what is possible' (1998, p. 126).

It is no exaggeration to say the United Kingdom is in a time of crisis. It is looking to leave the embrace of a key alliance at a dangerous time, with hugely uncertain effects for the economy and society, increasing its susceptibility to the actions of those who would harm it. It is conducting its foreign policy at a time when public mistrust in political and other elites is high: mistrust caused not only by the conduct of the EU referendum and the negotiations that followed but also by what most see as the lies that were told to the public prior to, during and after the Iraq war. No 10 and the Government are working too in an era in which a large percentage of the public get their news and ideas online, much of it from social media sources, and are vulnerable to the type of fake news and disinformation campaigns carried out by Russia and others, including the current President of the USA. The conduct of Brexit has had the effect of making the UK look weak, even vulnerable. No 10 will have to work even harder to retain what credibility remains to it. It can ill afford more slips such as those the former Foreign Secretary Boris Johnson committed when claiming scientists had confirmed Russia as the source of the novichok used in the attempt on Sergei Skripal's life when they most decidedly had not (Crerar, 2018). Such errors of judgement play in to Russia's hands. Russia's own Foreign Minister's claim that the British 'do not want to seek the truth' will not have been dismissed lightly by all onlookers (Lavrov in TASS, 2018). A kind interpretation of Johnson's time heading the FCO would conclude at least that he exuded confidence; the appointment of Jeremy Hunt as his replacement brings a different kind of problem. The new Foreign Secretary's tweet of August 22nd 2018, speaking of the 'honour' of meeting Henry Kissinger and referring to himself as 'the world's newest [diplomat]', ${ }^{9}$ showed naivety, not only about the, at best, dubious nature of Kissinger's legacy ${ }^{6}$ but about how, even in the best of times, one's own inexperience as a foreign policy actor is not something to be advertised. If the UK is to emerge from this crisis quickly, sure-footed, experienced and trustworthy leadership will be vital, as will be the ability to build cross-party political will to address systemic problems rather than just continuing to paper over the cracks. Surveying the current state of UK foreign policy, there is little about which to be optimistic.

A summing up of the arguments made here is simple. The Skripal poisonings represent another opportunity for the UK to wake up to the seriousness of the Russian challenge, to engage in making a foreign policy that is considered, directed and sustainable and that gives due regard for the resilience that policy, politics and people need to build. Failure to do so will rob this contemptible act of its only silver lining.
Received: 6 June 2018 Accepted: 28 August 2018

Published online: 11 September 2018

\section{Notes}

1 'Probably' has connotations in the context of Sir Robert Owen's final judgment on the death of Alexander Litvinenko, when he ruled: 'The FSB operation to kill Mr Litvinenko was probably approved by [...] President Putin' (House of Commons, 2016, p. 244)

2 Sergei Magnitsky was a lawyer working for Bill Browder after the seizure of his company, Hermitage Capital, by the Russian Interior Ministry. Magnitsky died in 2009 in a Russian prison after being beaten and denied access to urgent medical care. Browder has campaigned ever since for states to institute legislation that facilitates the imposition of visa sanctions and/or asset freezes on those involved in Magnitsky's death, as well as those committing human rights abuses in Russia.

3 See, for instance, the 2013 Foreign Policy Concept of the Russian Federation (Ministry of Foreign Affairs of the Russian Federation, 2013), where the link between a globalised world and the future security and prosperity of the Russian state is clearly made and the role of foreign policy in achieving that security and prosperity laid out. See Lukyanov, 2016 for an account of the concrete measures that have followed.

4 Conclusions about the role of leaders first and foremost reflect the intellectual home of the analyst, specifically whether they are scholars of International Relations more generally or Foreign Policy Analysis specifically. For a good account of the differences between Foreign Policy Analysis and various IR theories, see Houghton, 2007. Second conclusions are dependent on whether an analyst privileges structure or agency in their analysis of foreign policy. For a comprehensive account of this important debate, see Friedman and Starr, 1997. This article is built, however, on the insights of those like Hudson, who draw on a long body of literature, especially related to (cognitive) psychology, in arguing for the importance of agency and for seeing that agency as belonging to decision-makers, rather than abstracting the decision-making process to the state, and in so doing, treating as if it were a person (see, most notably, Hudson's 2005 call).

5 See Jeremy Hunt's confirmed Twitter account: https://twitter.com/Jeremy_Hunt. 6 See Hitchens, 2002 for his arguments that Kissinger was a war criminal.

\section{References}

Coles Sir JGCMG (2000) Making foreign policy matter. RUSI J 145(3):1-7. https:// doi.org/10.1080/03071840008446524

Crerar P (2018, April 4) Skripal poisoning: deleted Foreign Office tweet leads to awkward questions. The Guardian. https://www.theguardian.com/uk-news/ 2018/apr/04/skripal-poisoning-deleted-foreign-office-tweet-leads-toawkward-questions. Accessed 20 April 2018

Friedman G, Starr H (1997) Agency, structure and international politics: from ontology to empirical enquiry. Routledge, London, New York

Hermann MD, Hagan JD (1998) International decision making: leadership matters. Foreign Policy No. 110, Special Edition: Frontiers of Knowledge. pp. 124-137

Heywood, Sir J (2017) How the Civil Service is preparing for Brexit. Civil Service Blog. https://civilservice.blog.gov.uk/2017/07/11/how-the-civil-service-ispreparing-for-brexit/. Accessed 25 April 2018

Hitchens C (2002) The Trial of Henry Kissinger. Verso, London, New York

House of Commons (2016) The Litvinenko Inquiry. Report into the death of Alexander Litvinenko. HC695

Houghton DP (2007) Reinvigorating the study of foreign policy decision making: towards a constructivist approach. Foreign Policy Anal 3:24-45

Hudson V (2005) Foreign policy analysis: actor-specific theory and the ground of international relations. Foreign Policy Anal 1:1.30

Hunt J (2018) Foreign Secretary's speech at the United States Institute For Peace. https://www.gov.uk/government/speeches/foreign-secretarys-speech-at-theunited-states-institute-for-peace. Accessed 25 Aug 2018

Legvold R (2014) Managing the New Cold War. What Moscow and Washington Can Learn from the Last One. Foreign Aff 93(4):74-84

Lukyanov F (2016) Putin's Foreign Policy. The Quest to Restore Russia's Rightful Place. Foreign Affairs, Comment. May/June 2016. https://www.foreignaffairs.com/ articles/russia-fsu/2016-04-18/putins-foreign-policy. Accessed 25 August 2018

Mairs N (2018) Senior MPs form cross-party group to tackle Russian government threat, PoliticsHome. https:/www.politicshome.com/news/uk/technology/ cybersecurity/news/94531/senior-mps-form-cross-party-group-tacklerussian. Accessed 25 April 2018

May T (2017, January 17) The government's negotiating objectives for exiting the EU: PM speech. GOV.UK. https://www.gov.uk/government/speeches/thegovernments-negotiating-objectives-for-exiting-the-eu-pm-speech. Accessed 20 April 2018

Ministry of Foreign Affairs of the Russian Federation (2013) The Foreign Policy Concept of the Russian Federation. http://www.mid.ru/en/foreign_policy/ 
official_documents/-/asset_publisher/CptICkB6BZ29/content/id/122186. Accessed 25 Aug 2018

Morgan S (2018) Interview. Fake news, disinformation, manipulation and online tactics to undermine democracy. J Cyber Policy 3(1):39-43. https://doi.org/ $10.1080 / 23738871.2018 .1462395$

Polyakova A, Fried D (2018, May 30). How democracies can defend against disinformation. War on the rocks. https://warontherocks.com/2018/05/ how-democracies-can-defend-against-disinformation/. Accessed 25 Aug 2018

TASS (2018) Lavrov expects Skripal himself to clarify Salisbury incident. http://tass. com/politics/994296. Accessed 25 April 2018

UK Parliament (2018a) Moscow's Gold: Russian Corruption in the UK. https:// publications.parliament.uk/pa/cm201719/cmselect/cmfaff/932/93204. htm\# idTextAnchor002. Accessed 26 May 2018

UK Parliament (2018b) Global Britain. https://publications.parliament.uk/pa/ $\mathrm{cm} 201719 / \mathrm{cmselect} / \mathrm{cmfaff} / 780 / 78005 . h t m \#$ idTextAnchor011. Accessed 20 April 2018

UK Parliament (2017a) The United Kingdom's relations with Russia: Government Response to the Committee's Seventh Report of Session 2016-17. https:// publications.parliament.uk/pa/cm201719/cmselect/cmfaff/332/33202.htm. Accessed 20 April 2018

UK Parliament (2017b, February 28) The United Kingdom's relations with Russia. https://publications.parliament.uk/pa/cm201617/cmselect/cmfaff/120/12008. htm\#_idTextAnchor057. Accessed 25 April 2018

\section{Additional information}

Competing interests: The author declares no competing interests.

Reprints and permission information is available online at http://www.nature.com/ reprints

Publisher's note: Springer Nature remains neutral with regard to jurisdictional claims in published maps and institutional affiliations.

(c) Open Access This article is licensed under a Creative Commons Attribution 4.0 International License, which permits use, sharing, adaptation, distribution and reproduction in any medium or format, as long as you give appropriate credit to the original author(s) and the source, provide a link to the Creative Commons license, and indicate if changes were made. The images or other third party material in this article are included in the article's Creative Commons license, unless indicated otherwise in a credit line to the material. If material is not included in the article's Creative Commons license and your intended use is not permitted by statutory regulation or exceeds the permitted use, you will need to obtain permission directly from the copyright holder. To view a copy of this license, visit http://creativecommons.org/ licenses/by/4.0/.

(c) The Author(s) 2018 